\title{
Governing Forest Ecosystem Services for Sustainable Environmental Governance: A Review
}

\author{
Shankar Adhikari ${ }^{1, *}$ (iD) and Himlal Baral ${ }^{2}$ (i) \\ 1 Department of Forests, Ministry of Forests and Environment, Babarmahal, Kathmandu, Nepal \\ 2 Center for International Forestry Research, Jalan CIFOR, Situ Gede, Sindang Barang, Bogor 16115, Barat, \\ Indonesia; H.Baral@cgiar.org \\ * Correspondence: adhikarishankar@gmail.com; Tel.: +977-984-711-3360
}

Received: 14 March 2018; Accepted: 21 April 2018; Published: 2 May 2018

\begin{abstract}
Governing forest ecosystem services as a forest socio-ecological system is an evolving concept in the face of different environmental and social challenges. Therefore, different modes of ecosystem governance such as hierarchical, scientific-technical, and adaptive-collaborative governance have been developed. Although each form of governance offers important features, no one form on its own is sufficient to attain sustainable environmental governance (SEG). Thus, the blending of important features of each mode of governance could contribute to SEG, through a combination of both hierarchical and collaborative governance systems supported by scientifically and technically aided knowledge. This should be further reinforced by the broad engagement of stakeholders to ensure the improved well-being of both ecosystems and humans. Some form of governance and forest management measures, including sustainable forest management, forest certification, and payment for ecosystem services mechanisms, are also contributing to that end. While issues around commodification and putting a price on nature are still contested due to the complex relationship between different services, if these limitations are taken into account, the governance of forest ecosystem services will serve as a means of effective environmental governance and the sustainable management of forest resources. Therefore, forest ecosystem services governance has a promising future for SEG, provided limitations are tackled with due care in future governance endeavors.
\end{abstract}

Keywords: forest; ecosystem services; governance; management

\section{Introduction}

Governance of forest ecosystem services (FES), which leads to benefits for human well-being derived from forest ecosystems [1], is gaining traction these days as a critical component of contemporary environmental governance [2,3]. The concept of governance is the sum of the many ways that individuals and institutions, both private and public, coordinate and manage their complex and common affairs [3-5]. The governance of FES refers to the interaction of laws and other norms, institutions, and processes through which a society exercises powers and responsibilities to make and implement decisions affecting forest-related ecosystem services [3]. Therefore, governments are not the only authority to establish rules for the governance of FES [2]. Instead, FES governance involves the interplay of governmental, intergovernmental, and nongovernmental institutions, the private sector, and civil society, based on the rules and regulations established by customary and statutory law [3]. As a result, governance can work in two directions. For example, the legal framework influences the institutional framework and instruments, whereas locally tested instruments can also initiate the creation of adequate and appropriate laws and institutions, both on regional and national levels [3]. 
On the other hand, the scope of FES has shifted from the use of distinct components of ecosystems in the past, to improving long-term human well-being through the use of various ecosystem services in recent years [6]. Fostering overall human well-being is possible through a suite of ecosystem services, such as provisioning, regulating, cultural, and supporting services [1,7]. The variety of goods and services from forest ecosystems provides both opportunities and complexities in governing FES. For example, different services from the forest interact in a complex and dynamic manner, and the roles of governance come in generating the synergies and minimizing the negative trade-offs that could ultimately contribute to human well-being [6].

Even though the role of FES is widely acknowledged in various sectors, there still exist several challenges, due to the multiplicity of actors, institutions, knowledge, and processes involved in governance [8-10]. Further, contemporary environmental problems have made the governance of FES even more complex and challenging. Major environmental challenges include deforestation and forest degradation, coupled with unsustainable consumption of forest goods and services [11]. For example, since 2010, 3.3 million ha of forest have been lost each year [12]. This is further supported by the data released by Global Forest Watch in 2016. Global tree cover loss reached a record 29.7 million ha in that year, which is $51 \%$ higher than the previous year [13]. The losses in forest and tree cover have wide implications for different FES, which in turn have consequences for people who are dependent on different tangible and intangible FES $[12,14]$. This is particularly true in developing countries in the Himalayan regions, where significant numbers of people are dependent on goods and services from the forest for their livelihood [14].

Human communities and forests thus act as a forest socio-ecological system [15]. The forest socio-ecological system is an integrated approach based on the concept of humans in nature, emphasizing the entwined relationships between social and ecological systems [7,16]. It replaces the nature-culture dichotomy and regards delineation between them as arbitrary and artificial [17], in concordance with the principle of ecological solidarity as an interdependence between nature and society [18].

The principle of ecological solidarity provides a conceptual basis for the socio-ecological interdependence that not only reconnects ecological process and management practices but also supports the local communities with social, economic, and environmental benefits in a sustainable manner [18]. Ecological solidarity therefore creates interdependence and interconnectedness between human beings, with a close collaboration among different stakeholders and ecosystems $[18,19]$, which helps develop a sense of ownership and motivation towards nature conservation. Furthermore, human societies will also be more responsible for their actions and consequences. As human societies become responsible for the future consequences of their present activities while governing FES, it also supports principles of foresight. In other words, the foresight principles place the care of future generations as the main priority, rather than discounting it in favor of short-term fiscal advantages and/or comforts [20]. Both the principles of ecological solidarity and the foresight principles might work as a foundation for sustainable environmental governance (SEG).

SEG is governance that ensures ecosystem integrity, economic efficiency, equity, and political legitimacy [21]. However, the complexity of forest socio-ecological systems has rendered governance quite challenging. Moreover, the concept of governance has broadened from the earlier one of governance as a process of governing, such as decision-making and ruling throughout society [22], to quite a broad and complex one incorporating organizational hybrids that cross hierarchies, networks, and markets, and including multiple actors from the public, private, and voluntary sectors [22,23]. This paper therefore argues that management of forest ecosystem services within the forest socio-ecological system promotes SEG.

The paper will begin by briefly discussing the methods of the study and different modes of governance in FES. Then it will examine two forest ecosystem governance frameworks and their practical examples, as compared with SEG, and end with a brief conclusion. 


\section{Methods}

The study is based on a literature search in various web-based databases [24-26], and the methodological approach is illustrated in Figure 1. The web-based databases used are Google Scholar, ISI Web of Science, Science Direct, and Scopus. The search was primarily focused on the governance of forest ecosystem services. The key terms used during the search were "Forest" OR "Ecosystem service(s)" OR "Governance". In addition, several kinds of word combinations were also used to find more articles (Figure 1). First-round screening was done based on a quick review of title, abstract, and keywords in the articles. In addition to peer-reviewed articles, we also used conference proceedings, technical reports, government publications, and book chapters during the review process.

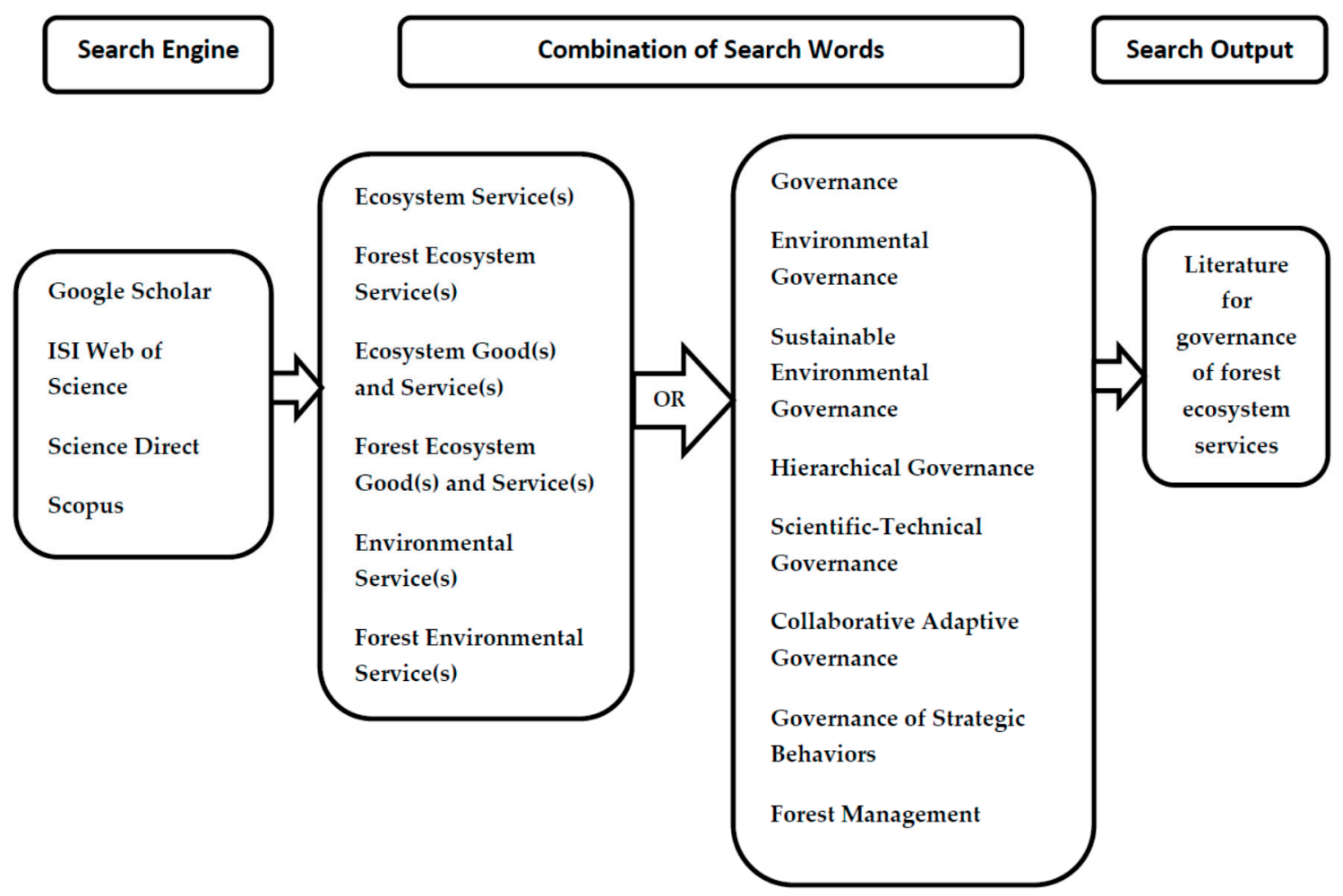

Figure 1. Methodology adopted for literature search using keywords in various web-based databases.

\section{Governance of Forest Ecosystem Services: Conceptual Evolution}

With the growing interest in the concept of FES worldwide, different modes of governance of these services have evolved. The ecosystem services (ES) concept first appeared in the 1980s [27] and became prominent in 2005 with the release of the Millennium Ecosystem Assessment [28]. Now it is widely recognized as a concept for the benefit of both nature and human well-being derived from healthy ecosystems [1,6]. Different modes of governing these services have evolved with the development of the concept of ES: (1) Hierarchical governance, (2) scientific-technical governance, (3) adaptive collaborative governance, and (4) governance of strategic behaviors [29].

\subsection{Hierarchical Governance}

Hierarchical FES governance encompasses the way in which international decisions and policies are prepared, and how these will help frame national-level policy and implementation [29]. The Convention on Biological Diversity (CBD), for example, is a multilateral environmental agreement, with several provisions for biodiversity conservation, which are reflected as governing policy documents for biodiversity and ecosystem management at national and local levels in the member states [30,31]. The Economics of Ecosystems and Biodiversity (TEEB) is another approach being 
practiced at the national level in the United Kingdom, Belgium, and The Netherlands, mainly to develop integrated decision-making systems for ES [32].

As much effort goes into monitoring and reporting on the progress towards policy targets at the national level, it has raised concerns as to whether such global monitoring and reporting help guide conservation actions effectively at national and subnational levels [33]. Similarly, indicators used for these purposes are also inconsistent. Furthermore, conservation and management of ES require long-term commitments made by national governments under the premises of international conventions. However, these previously approved commitments and policies can be threatened or simply terminated by changes in power or government [33,34].

Different actors, including those from both government and nongovernment sectors, are involved in the management of FES. Even though multi-stakeholders engagement might bring ownership to the governance process, there is also the danger of individuals and institutions in positions of power narrowly interpreting such international policy frameworks to serve their own purposes in terms of national policy [29]. For example, government agencies, in general, place emphasis on regulating, cultural and aesthetic types of ES, whereas the public and users of the FES at the grass roots level are more interested in provisioning services to meet their daily requirements, especially in rural settings in developing countries. Therefore, assessments and recommendations, such as those delivered by the CBD and by the Intergovernmental Platform for Biodiversity and Ecosystem Services (IPBES), should focus on decision-makers in the government, and also on the many actors involved in the fields of biodiversity and ecosystems [33].

Furthermore, in some cases, international policies are less ambitious than national policies that are already in place. For example, while the CBD requires member states to have at least $17 \%$ of their land as protected areas [35], in Nepal, $23.23 \%$ of the land is already designated and governed as protected areas [36]. Therefore, there needs to be caution in applying these policies, in line with realities in the field. Similarly, we should promote mainstreaming forest ES in national and subnational policies and guidelines $[37,38]$, which should be further strengthened by developing dedicated financing mechanisms, and developing better tools to help policy makers exploit cross-sectoral synergies and manage trade-offs between ES [37].

\subsection{Scientific-Technical Governance}

Scientific-technical governance is another form of ecosystem service governance that supports both hierarchical policy formulation and the bottom-up approach of policy, by supplying required technical and scientific input $[29,39]$. For example, it provides cutting-edge knowledge in the field of FES and helps to produce an effective policy framework at national and local levels. A major feature of this sort of governance is the incorporation of science-based arguments into policies and practical governance situations [40]. However, there are problems with smooth knowledge flow, communication, and broad public participation, which affect the overall FES governance [29]. For example, scientifically embedded and technically aided policy and practice are sometimes difficult for policy makers and local communities to understand [41,42]. Therefore, there needs to be external support and a buildup of stakeholders' capacity.

Further, only a thorough understanding of how social and ecological systems interact to produce ecosystem services can address issues of governance. For this, more integrative collaboration on studies about complex forest socio-ecological systems across social sciences, natural sciences, and the humanities is required [43]. Similarly, widespread mismatches between governance needs and ES approaches, if any, can be closed by developing tools built on existing knowledge systems and governance arrangements [44]. More importantly, these findings should be communicated across ecosystem and sector boundaries [44]. 


\subsection{Adaptive Collaborative Governance}

Considering the lack of adequate stakeholder engagement and of broader public ownership resulting from hierarchical and scientific knowledge-based governance, adaptive collaborative governance came to the fore to overcome these problems $[29,45,46]$. The major aim of this approach is to integrate arguments from both analytical and pragmatic points of view, and underscore the importance of norms and stakeholder commitment to achieve broader ownership and effective implementation as collective governance $[29,47,48]$. The particular features of adaptive collaborative governance are that it provides a theoretical basis for research that combines analyses of novel governance capacities, such as adaptive capacity, collaboration, scaling, knowledge, and learning [46].

The approach is primarily bottom-up and emphasizes methods of sustainable governance, such as participatory decision-making and implementation [49]. More importantly, methods are context-specific based on a learning-by-doing modus operandi and do not follow the blueprint approach of one-size-fits-all. The community forestry program of Nepal is a good example of adaptive collaborative governance, in which national policy was formulated based on a series of pilot studies of forest management and governance in the field, and later scaled up as a community forestry program throughout the country by the Forest Act 1993 [50,51]. As a result, community forest user groups have now self-organized as a social network and promoted resilient forest socio-ecological systems [52].

\subsection{Governance of Strategic Behaviors}

Despite every effort to involve all stakeholders in FES governance, some sections of society and their interests might be overlooked, and there are risks that these sections of the community will pose challenges or create barriers to implementation [53]. For example, if some stakeholders fear economic loss due to conservation efforts around ES, they might argue against the conservation policy and governance mechanism [29,54]. A form of governance called governance of strategic behaviors [55] helps to incorporate the dissenting views on governance processes as far as possible [56].

Each mode of governance has important features. The main advantages and limitations of each mode of governance are summarized in Table 1.

Table 1. Advantages and limitations of the forest ecosystem services (FES) governance approach.

\begin{tabular}{|c|c|c|}
\hline $\begin{array}{l}\text { Governance } \\
\text { Approach }\end{array}$ & Advantages & Limitations \\
\hline $\begin{array}{l}\text { Hierarchical } \\
\text { governance }\end{array}$ & $\begin{array}{l}\text { - Provides framework for national policies and } \\
\text { further support to local-level governance. } \\
\text { - International environmental decisions are } \\
\text { filtered to national policies. } \\
\text { - Gives uniformity in policy among nation states. } \\
\text { Opportunities exist for nation states to share } \\
\text { and review their progress, and for } \\
\text { further refinement. }\end{array}$ & $\begin{array}{l}\text { - } \quad \text { Top-down approach is used. } \\
\text { - Certain powerful actors and sectors could } \\
\text { narrowly interpret broadly defined } \\
\text { international commitments. } \\
\text { Local issues and actors may not be properly } \\
\text { represented in decision-making, resulting in } \\
\text { lack of ownership over the process. } \\
\text { Transfer of arguments occurs in } \\
\text { multilateral governance. }\end{array}$ \\
\hline $\begin{array}{l}\text { Scientific- } \\
\text { technical } \\
\text { governance }\end{array}$ & $\begin{array}{l}\text { - } \quad \text { Maximizes the effectiveness in reaching } \\
\text { policy goals. } \\
\text { - Supports scientifically and technically sound } \\
\text { policy and governance. } \\
\text { - Scientists are considered as } \\
\text { important stakeholders. }\end{array}$ & $\begin{array}{l}\text { - Scientifically aided policy might be different } \\
\text { from local and indigenous practices, } \\
\text { resulting in unexpected friction in } \\
\text { implementation and impending the overall } \\
\text { effectiveness of the program. } \\
\text { - Inadequate technical knowledge for } \\
\text { reaching the policy goal may be even } \\
\text { more problematic. } \\
\text { - Scale mismatch may exist between the } \\
\text { decision context and available data, and the } \\
\text { communication process between them. } \\
\text { Scientists may dominate in the } \\
\text { policy process. }\end{array}$ \\
\hline
\end{tabular}


Table 1. Cont.

\begin{tabular}{|c|c|c|}
\hline $\begin{array}{l}\text { Governance } \\
\text { Approach }\end{array}$ & Advantages & Limitations \\
\hline $\begin{array}{l}\text { Adaptive } \\
\text { collaborative } \\
\text { governance }\end{array}$ & $\begin{array}{l}\text { Involves a collaborative bottom-up } \\
\text { governance approach. } \\
\text { Broad argumentation/integration of both } \\
\text { analytical and pragmatic arguments occurs. } \\
\text { - Stakeholder engagement is inclusive. } \\
\text { Because the modus operandi involves } \\
\text { learning-by-doing, there is local engagement } \\
\text { and ownership over the process. } \\
\text { - The participatory process is well organized. } \\
\text { - Involves collective learning, knowledge } \\
\text { accumulation and sharing, and sensitivity } \\
\text { to change. } \\
\text { - Has positive socio-ecological outcomes. }\end{array}$ & $\begin{array}{l}\text { - Complexity in decision-making and overall } \\
\text { governance exists due to large numbers } \\
\text { of stakeholders. } \\
\text { Balancing both hierarchical and } \\
\text { scientific-technical governance is } \\
\text { quite tricky. }\end{array}$ \\
\hline $\begin{array}{l}\text { Governance of } \\
\text { strategic } \\
\text { behaviors }\end{array}$ & $\begin{array}{l}\text { Encourages proactive stances and provides } \\
\text { opportunity for redefining and } \\
\text { reframing policy. } \\
\text { Opportunity to gain the confidence of those } \\
\text { stakeholders negatively affected by } \\
\text { conservation policies and governance processes, } \\
\text { both in policy making and implementation, and } \\
\text { to involve them throughout the process. }\end{array}$ & $\begin{array}{l}\text { - If those affected stakeholders are in a } \\
\text { position to dominate the policy and } \\
\text { implementation discourse, they might argue } \\
\text { against the policy. } \\
\text { - Not a "one-size-fit-all" solution, but it } \\
\text { depends rather on various contexts } \\
\text { and situations. }\end{array}$ \\
\hline
\end{tabular}

However, not one of these systems is sufficient for SEG on its own. Still, there is potential to incorporate beneficial features from each mode of governing FES, such as science-based knowledge in both international policy process and adaptive collaborative governance, while embracing the dissenting views at both the national and local levels. The resulting governance framework now can be regarded as SEG in general, and sustainable governance of FES in particular.

Against these set SEG definitions and criteria, two important FES governance frameworks, viz. sustainable forest management and payment for ecosystem services, will be examined as illustrative examples to assess the importance of these instruments for environmentally sustainable governance.

\section{Sustainable Forest Management}

Sustainable forest management (SFM) is a forest governance approach to tackling unsustainable use of forest resources, by promoting sustainable production of different goods and services from the forest [57]. Therefore, SFM considers the needs of both present and future generations, while addressing the challenges of meeting increased demands of a growing population and maintaining healthy forest ecosystems [58]. Criteria and indicators (C\&Is) of SFM and forest certification are two major policy instruments that support SFM practice.

C\&Is work as a basis for measuring the changes in forest condition and promote SFM at national, subnational, and forest management unit levels. The Montreal process of C\&Is and the International Tropical Timber Organization (ITTO) C\&Is processes are major governance instruments used mainly in temperate and tropical nations, respectively [59]. Although these operate in different regions, their common goals are to promote SFM in their respective regions. However, most of these C\&Is are heavily based on top-down approaches at the regional level, which might not be applicable in the field [60]. To address this drawback, some community-based forest management initiatives, such as community forest management and collaborative forest management, are based on local indigenous knowledge [61].

Forest certification is another equally important instrument of sustainable forest governance, in which a third-party, independent certifier assesses the quality of forest management against predetermined standards [62]. If forest management and overall governance are found to be compliant 
with the pre-set criteria, forest management and forest products are given written assurance as certified products [63]. Forest certification creates awareness about using products from sustainably managed forests and adopts sustainable consumption patterns; it also helps the banning of products from uncertified forests and thereby reduces illegal harvesting. This will eventually lead to sustainable forest management [64]. For example, the Forest Stewardship Council (FSC) and Pan European Forest Certification (PEFC) are major forest certification initiatives in tropical and temperate countries [65].

However, as is the case for the C\&Is framework for SFM, forest certification is also heavily dependent on a top-down approach, and local issues are not properly addressed. Similarly, it is still hard to measure how far certification schemes are successful in achieving sustainability governance, although they offer improvements in forest management and bring different stakeholders on board [63]. Furthermore, they involve heavy costs, so developing and resource-poor countries could not afford the cost on their own [66]. Therefore, some even perceive certification as a trade-related barrier imposed by developed nations on the developing world, the nations of which cannot afford the cost and cumbersome bureaucratic procedures needed for the certification [63]. In other words, developing countries and countries in transition might not afford the forest certification on their own. As a result, forest products from uncertified forests could not go into the market in the absence of forest certification.

A recent study by Tian et al. [67] in Shandong province of China has made interesting observations on benefits and drawbacks of forest certification in China, and the potential ways to tackle with these drawbacks. The perceived benefits include increased timber growth and health, expanded markets for harvested forest products, price premiums for harvested forest products, public recognition for practicing responsible forestry, environmentally friendly timber harvesting, and better management practices [67]. On the other hand, the potential drawbacks are the increased cost of forest management, increased record keeping and paperwork, periodic on-site inspections of forestry practices, adherence to a forest management plan, and decreased diversity in types of potential timber harvesting practices [67]. For example, as the cost of forest certification is considered as one of the important barriers for landowners to participate in the certification program in China, establishing some incentive-based mechanism, such as provision of compensation, subsidies, and tax reduction, especially for small-scale forest landowners, could help to reduce the cost and attract landowners to the certification program [68]. Similarly, group certification might be useful to reduce the cost and other requirements of certification, such as increased paper work, thereby promoting landowners' interest in forest certification. Therefore, considering the fact that certification alone may be insufficient to the sustainability of forest resource management in China, the country has initiated new policy instruments, such as the Natural Forest Protection Program and Grain to Green Program, to accommodate both economic and environmental interests, from both markets and the government $[67,69]$. For example, the Natural Forest Protection Program bans commercial logging and helps restore protective watershed, whereas the Grain to Green Program is designed to increase vegetative cover and support forest landscape restoration $[67,69]$.

In summary, SFM is an advantageous approach to the framework for the governance of FES. However, it still has practical challenges, such as addressing the local-level C\&Is of SFM and certification. Therefore, attention must be paid to local forest management issues while formulating frameworks that blend both local and scientific knowledge in order to promote effective SEG.

\section{Payment for Ecosystem Services}

Payment for ecosystem services (PES) is a governing framework of ES based on the economic valuation of ES from forest socio-ecological systems [70]. It is primarily founded on market-based policy to realize hypothetical or even unrecognized market value in real cash flows, in which providers of ES are paid by the beneficiaries of these services [71]. In order to realize these market-based approaches, there needs to be compartmentalization of services from the forest, and their commodification as a tradable commodity [72]. Major ES promoted through PES as commodification are watershed protection, biodiversity conservation, carbon sequestration, and aesthetic and landscape beauty in 
forest-dominated socio-ecological landscapes [73]. Therefore, it is based on the beneficiary-pays rather than of polluter-pays principles [74].

The major benefits of PES schemes are that they recognize and communicate the relationship between economic processes and ecosystem functions. The schemes help to solve the tension between environmental conservation and economic development in an effort to create the win-win situation of ecosystem integrity and human well-being [72,75]. Further, PES makes the linkage between resource-based users managing FES and the beneficiaries of these services [76]. Latin American countries are pioneers in promoting PES [77]. For example, Costa Rica has a remarkable track record of extensive PES implementation as an innovative means to sustainable forest management, in which land users and managers are paid for their contributions to new plantations, sustainable logging, and natural forest conservation [78]. As a result, the scheme contributes to water catchment protection, for which hydroelectric power generators and other industrial water users pay for upstream communities to conserve resources [79].

Similarly, reducing emissions from deforestation and degradation (REDD+) is a concept based on the premise of PES, which can be applied on a broader scale from local to regional levels [77]. It helps to generate incentives for the protection and better management of forests for carbon storage and sequestration in the forest, which were once considered to be non-market benefits [80]. Pilot studies of REDD+ in Nepal and Vietnam have shown this approach has a promising future in forest conservation and enhancing the well-being of nearby communities [81,82].

However, there are several limitations of PES mechanisms. First, valuation and payment mechanisms are primarily based on the compartmentalization and commodification of complex ES, which is not practical due to the nonlinear, multidimensional, and multi-scale nature of ecosystem dynamics in most cases [83,84]. Second, PES approaches do not accommodate complex relationships and instead significantly reduce such complexity in compartmentalizing ES into different units [71]. Therefore, compartmentalization and commodification of FES promote single-services-based governance, such as carbon, timber, and water, instead of integrated governance, to tackle complex problems. This simplification is exacerbated by the current practice of promoting isolated social and ecological policies instead of integrated socio-ecological policies and practices [84].

Furthermore, there is not a market mechanism for every service, especially intangible services such as cultural and spiritual values derived from the forest [85], and other supporting services, including nutrient cycling and soil formation [1]. It is indeed difficult to capture them in monetary value [72].

On the other hand, putting values on the different ES from forests and selling them to buyers could create possible opposition from those local and indigenous communities that have been managing and using these resources for a long time [85]. Similarly, buyers of the ES could use them without due consideration of environmental degradation. Most importantly, those who could not afford to pay for the services would not be able to derive benefits from the forest, which will have a significant effect on poor and marginalized sections of the community [83].

Overall, despite several challenges in governing ES as PES, the scheme still has potential to promote SEG. For instance, if the PES framework and examples are evaluated against the SEG definition and criteria as defined earlier, it contributes to both hierarchical and bottom-up governance, and ensures multi-stakeholders' collaboration, with the active engagement of government and nongovernment agencies and local communities. Similarly, although inadequate, REDD+ and PES policies and frameworks have been supported by different research and policy negotiations, such as the Convention on Biological Diversity, to some extent. Moreover, both approaches seem to have incorporated dissenting views into the governance as a means of governing strategic behavior. Therefore, PES could be regarded as an example of SEG. Yet, there are some areas that could be improved to make governance more effective and sustainable. For instance, criticism around commodification and monetary valuations could be addressed by promoting both monetary and nonmonetary assessments of tangible and intangible services. Similarly, certification could help to 
avoid unsustainable exploitation of resources. Most importantly, most of the stakeholders should be part of the governance and benefit-sharing process, so that it creates ownership of the resources among different stakeholders and contributes to both effective governance and utilization.

\section{Conclusions}

Governance of FES could be a viable option for SEG in the face of different environmental and social challenges. Despite various modes of governing FES, such as hierarchical, scientific-technical, and adaptive collaborative governance being in vogue, none of them are sufficient for SEG on their own. Further, there are some limitations, such as issues surrounding the commodification of nature in PES, and forest certification mostly not incorporating the local context. Therefore, the proper blending of important features of each mode of governance in governing FES in a context-specific manner could serve as a basis for the sustainable management of forest resources on the one hand, and contribute to SEG on the other. A combination of both hierarchical and collaborative governance supported by scientifically and technically aided knowledge could help to that end. For example, sustainable forest management, forest certification, and PES mechanisms are some examples of SEG, with the use of a combination of different approaches and effective stakeholder engagement. Therefore, governing FES holds promise if managed properly with the use of various modes of governance, while still addressing the current limitations.

Author Contributions: Shankar Adhikari drafted the manuscript. Himlal Baral provided conceptual guidance, polished and revised the manuscript. Both authors read and approved the final manuscript.

Funding: This research received no external funding.

Acknowledgments: We acknowledge the CGIAR Research Program on Forests, Trees and Agroforestry and the Republic of Austria for making this article available to all by sponsoring CIFOR's payment of the journals Article Processing Charge. We also appreciate the constructive suggestions made by anonymous reviewers to improve the paper.

Conflicts of Interest: The authors declare no conflicts of interest.

\section{References}

1. MEA. Ecosystems and Human Well-Being; Millennium Ecosystem Assessment; Island Press: Washington, DC, USA, 2005; p. 5.

2. Dias, L.F.O.; Dias, D.V.; Magnusson, W.E. Influence of environmental governance on deforestation in municipalities of the Brazilian Amazon. PLoS ONE 2015, 10, 0131425. [CrossRef] [PubMed]

3. Greiber, T.; Schiele, S. Governance of Ecosystems Services: Lessons Learned from Cameroon, China, Costa Rica and Ecuador; International Union for Conservation of Nature (IUCN): Gland, Switzerland, 2011; p. 79.

4. Commission on Global Governance. Our Global Neighbourhood: The Report of the Commission on Global Governance; Oxford University Press: Oxford, UK, 1995.

5. Seyle, D.C.; King, M.W. Understanding governance. In State of the World 2014; Island Press: Washington, DC, USA, 2014; pp. 20-28.

6. Paavola, J.; Hubacek, K. Ecosystem services, governance, and stakeholder participation: An introduction. Ecol. Soc. 2013, 18. [CrossRef]

7. Steffen, W.; Persson, Å.; Deutsch, L.; Zalasiewicz, J.; Williams, M.; Richardson, K.; Crumley, C.; Crutzen, P.; Folke, C.; Gordon, L. The Anthropocene: From global change to planetary stewardship. Ambio 2011, 40, 739-761. [CrossRef] [PubMed]

8. Loft, L.; Mann, C.; Hansjürgens, B. Challenges in ecosystem services governance: Multi-levels, multi-actors, multi-rationalities. Ecosyst. Serv. 2015, 16, 150-157. [CrossRef]

9. Spangenberg, J.H.; Görg, C.; Settele, J. Stakeholder involvement in ESS research and governance: Between conceptual ambition and practical experiences-Risks, challenges and tested tools. Ecosyst. Serv. 2015, 16, 201-211. [CrossRef]

10. Durant, R.F.; Fiorino, D.J. Environmental Governance Reconsidered: Challenges, Choices, and Opportunities; MIT Press: Cambridge, MA, USA, 2017. 
11. Pandit, M.K.; Kumar, V. Land-Use Change and Conservation Challenges in the Indian Himalaya. Conserv. Biol. Voices Trop. 2007, 121-133. [CrossRef]

12. Keenan, R.J.; Reams, G.A.; Achard, F.; de Freitas, J.V.; Grainger, A.; Lindquist, E. Dynamics of global forest area: Results from the FAO Global Forest Resources Assessment 2015. For. Ecol. Manag. 2015, 352, 9-20. [CrossRef]

13. Global Forest Watch 2017. Global Tree Cover Loss Rose 51 Percent in 2016. Available online: https://blog. globalforestwatch.org/data/global-tree-cover-loss-rose-51-percent-in-2016.html (accessed on 9 April 2018).

14. Adhikari, S.; Baral, H.; Nitschke, C. Adaptation to climate change in Panchase Mountain ecological regions of Nepal. Environments 2018, 5, 42. [CrossRef]

15. Kalaba, F.K. A conceptual framework for understanding forest socio-ecological systems. Biodivers. Conserv. 2014, 23, 3391-3403. [CrossRef]

16. Berkes, F.; Folke, C.; Colding, J. Linking Social and Ecological Systems: Management Practices and Social Mechanisms for Building Resilience; Cambridge University Press: Cambridge, UK, 2000.

17. Farhad, S.; Gual, M.A.; Ruiz-Ballesteros, E. Linking governance and ecosystem services: The case of Isla Mayor (Andalusia, Spain). Land Use Policy 2015, 46, 91-102. [CrossRef]

18. Thompson, J.D.; Mathevet, R.; Delanoë, O.; Gil-Fourrier, C.; Bonnin, M.; Cheylan, M. Ecological solidarity as a conceptual tool for rethinking ecological and social interdependence in conservation policy for protected areas and their surrounding landscape. Comptes Rendus Biol. 2011, 334, 412-419. [CrossRef] [PubMed]

19. Schultz, P.W. Inclusion with nature: The psychology of human-nature relations. In Psychology of Sustainable Development; Springer: Berlin, Germany, 2002; pp. 61-78.

20. Destatte, P. Foresight: A major tool in tackling sustainable development. Technol. Forecast. Soc. Chang. 2010, 77, 1575-1587. [CrossRef]

21. Adger, W.N.; Brown, K.; Fairbrass, J.; Jordan, A.; Paavola, J.; Rosendo, S.; Seyfang, G. Governance for sustainability: Towards a 'thick' analysis of environmental decision making. Environ. Plan. 2003, 35, 1095-1110. [CrossRef]

22. Manwaring, R. Governance: A Very Short Introduction by Mark Bevir; Oxford University Press: Oxford, UK, 2012; 132p, ISBN 978-0-19 960641-2.

23. Turnpenny, J.; Russel, D.; Jordan, A. The challenge of embedding an ecosystems approach: Patterns of knowledge utilisation in public policy appraisal. Environ. Plan. C Gov. Policy 2014, 32, 247-262. [CrossRef]

24. Kulkarni, A.V.; Aziz, B.; Shams, I.; Busse, J.W. Comparisons of citations in web of science. JAMA 2009, 302, 1092-1096. [CrossRef] [PubMed]

25. Alamgir, M.; Pert, P.L.; Turton, S.M. A review of ecosystem services research in Australia reveals a gap in integrating climate change and impacts on ecosystem services. Int. J. Biodivers. Sci. Ecosyst. Serv. Manag. 2014, 10, 112-127. [CrossRef]

26. Paudyal, K.; Baral, H.; Lowell, K.; Keenan, R.J. Ecosystem services from community-based forestry in Nepal: Realising local and global benefits. Land Use Policy 2017, 63, 342-355. [CrossRef]

27. Chaudhary, S.; McGregor, A.; Houston, D.; Chettri, N. The evolution of ecosystem services: A time series and discourse-centered analysis. Environ. Sci. Policy 2015, 54, 25-34. [CrossRef]

28. Duraiappah, A.K.; Naeem, S.; Agardy, T.; Assessment, M.E. Ecosystems and Human Well-being: Biodiversity Synthesis; Island Press: Washington, DC, USA, 2005.

29. Primmer, E.; Jokinen, P.; Blicharska, M.; Barton, D.N.; Bugter, R.; Potschin, M. Governance of ecosystem services: A framework for empirical analysis. Ecosyst. Serv. 2015, 16, 158-166. [CrossRef]

30. Beunen, R.; Van der Knaap, W.G.; Biesbroek, G.R. Implementation and integration of EU environmental directives. Experiences from The Netherlands. Environ. Policy Gov. 2009, 19, 57-69. [CrossRef]

31. Butchart, S.H.; Walpole, M.; Collen, B.; Van Strien, A.; Scharlemann, J.P.; Almond, R.E.; Baillie, J.E.; Bomhard, B.; Brown, C.; Bruno, J. Global biodiversity: Indicators of recent declines. Science 2010, 328, 1164-1168. [CrossRef] [PubMed]

32. Verburg, R.; Selnes, T.; Verweij, P. Governing ecosystem services: National and local lessons from policy appraisal and implementation. Ecosyst. Serv. 2016, 18, 186-197. [CrossRef]

33. Geijzendorffer, I.R.; van Teeffelen, A.J.; Allison, H.; Braun, D.; Horgan, K.; Iturrate-Garcia, M.; Santos, M.J.; Pellissier, L.; Prieur-Richard, A.H.; Quatrini, S.; et al. How can global conventions for biodiversity and ecosystem services guide local conservation actions? Curr. Opin. Environ. Sustain. 2017, 29, 145-150. [CrossRef] 
34. Bomberg, E. Environmental politics in the Trump era: An early assessment. Environ. Politics 2017, 26, 956-963. [CrossRef]

35. Woodley, S.; Bertzky, B.; Crawhall, N.; Dudley, N.; Londoño, J.M.; MacKinnon, K.; Redford, K.; Sandwith, T. Meeting Aichi Target 11: What does success look like for protected area systems? Parks 2012, 18, $23-36$.

36. Heinen, J.T.; Shrestha, S.K. Evolving policies for conservation: An historical profile of the protected area system of Nepal. J. Environ. Plan. Manag. 2006, 49, 41-58. [CrossRef]

37. Bouwma, I.; Schleyer, C.; Primmer, E.; Winkler, K.J.; Berry, P.; Young, J.; Carmen, E.; Špulerová, J.; Bezák, P.; Preda, E.; et al. Adoption of the ecosystem services concept in EU policies. Ecosyst. Serv. 2017, 29, 213-222. [CrossRef]

38. Chaudhary, S.; McGregor, A. A critical analysis of global ecosystem services (Paristhitiki sewa) discourse in Nepal. Land Use Policy 2018, 75, 364-374. [CrossRef]

39. Sutherland, W.J.; Pullin, A.S.; Dolman, P.M.; Knight, T.M. The need for evidence-based conservation. Trends Ecol. Evol. 2004, 19, 305-308. [CrossRef] [PubMed]

40. Vihervaara, P.; Kumpula, T.; Ruokolainen, A.; Tanskanen, A.; Burkhard, B. The use of detailed biotope data for linking biodiversity with ecosystem services in Finland. Int. J. Biodivers. Sci. Ecosyst. Serv. Manag. 2012, 8, 169-185. [CrossRef]

41. Daily, G.C.; Polasky, S.; Goldstein, J.; Kareiva, P.M.; Mooney, H.A.; Pejchar, L.; Ricketts, T.H.; Salzman, J.; Shallenberger, R. Ecosystem services in decision making: Time to deliver. Front. Ecol. Environ. 2009, 7, 21-28. [CrossRef]

42. Muradian, R.; Rival, L. Ecosystem services and environmental governance: Some concluding remarks. In Governing the Provision of Ecosystem Services; Springer: Berlin, Germany, 2013; pp. 465-471.

43. Bennett, E.M.; Cramer, W.; Begossi, A.; Cundill, G.; Díaz, S.; Egoh, B.N.; Geijzendorffer, I.R.; Krug, C.B.; Lavorel, S.; Lazos, E.; et al. Linking biodiversity, ecosystem services, and human well-being: Three challenges for designing research for sustainability. Curr. Opin. Environ. Sustain. 2015, 14, 76-85. [CrossRef]

44. Primmer, E.; Furman, E. Operationalising ecosystem service approaches for governance: Do measuring, mapping and valuing integrate sector-specific knowledge systems? Ecosyst. Serv. 2012, 1, 85-92. [CrossRef]

45. Williams, B.K. Adaptive management of natural resources-Framework and issues. J. Environ. Manag. 2011, 92, 1346-1353. [CrossRef] [PubMed]

46. Karpouzoglou, T.; Dewulf, A.; Clark, J. Advancing adaptive governance of social-ecological systems through theoretical multiplicity. Environ. Sci. Policy 2016, 57, 1-9. [CrossRef]

47. Marshall, G.R. Polycentricity, reciprocity, and farmer adoption of conservation practices under community-based governance. Ecol. Econ. 2009, 68, 1507-1520. [CrossRef]

48. Ostrom, E. A Polycentric Approach for Coping with Climate Change; The World Bank: Washington, DC, USA, 2009.

49. Fraser, E.D.; Dougill, A.J.; Mabee, W.E.; Reed, M.; McAlpine, P. Bottom up and top down: Analysis of participatory processes for sustainability indicator identification as a pathway to community empowerment and sustainable environmental management. J. Environ. Manag. 2006, 78, 114-127. [CrossRef] [PubMed]

50. Acharya, K.P. Twenty-four years of community forestry in Nepal. Int. For. Rev. 2002, 4, 149-156. [CrossRef]

51. Pokharel, B.K.; Branney, P.; Nurse, M.; Malla, Y.B. Community forestry: Conserving forests, sustaining livelihoods and strengthening democracy. J. For. Livelihood 2007, 6, 8-19.

52. Folke, C.; Hahn, T.; Olsson, P.; Norberg, J. Adaptive governance of social-ecological systems. Annu. Rev. Environ. Resour. 2005, 30, 441-473. [CrossRef]

53. Hiedanpää, J.; Bromley, D.W. The harmonization game: Reasons and rules in European biodiversity policy. Environ. Policy Gov. 2011, 21, 99-111. [CrossRef]

54. Rivera, J.; Oetzel, J.; Starik, M. Business responses to environmental and social protection policies: Toward a framework for analysis. Policy Sci. 2009, 42, 3-32. [CrossRef]

55. Cashore, B.; Vertinsky, I. Policy networks and firm behaviours: Governance systems and firm responses to external demands for sustainable forest management. Policy Sci. 2000, 33, 1-30. [CrossRef]

56. Primmer, E. Analysis of institutional adaptation: Integration of biodiversity conservation into forestry. J. Clean. Prod. 2011, 19, 1822-1832. [CrossRef]

57. Siry, J.P.; Cubbage, F.W.; Ahmed, M.R. Sustainable forest management: Global trends and opportunities. For. Policy Econ. 2005, 7, 551-561. [CrossRef] 
58. MacDicken, K.G.; Sola, P.; Hall, J.E.; Sabogal, C.; Tadoum, M.; de Wasseige, C. Global progress toward sustainable forest management. For. Ecol. Manag. 2015, 352, 47-56. [CrossRef]

59. Wijewardana, D. Criteria and indicators for sustainable forest management: The road travelled and the way ahead. Ecol. Indic. 2008, 8, 115-122. [CrossRef]

60. Pearce, D.; Putz, F.E.; Vanclay, J.K. Sustainable forestry in the tropics: Panacea or folly? For. Ecol. Manag. 2003, 172, 229-247. [CrossRef]

61. Armitage, D. Adaptive capacity and community-based natural resource management. Environ. Manag. 2005, 35, 703-715. [CrossRef] [PubMed]

62. Cashore, B.W.; Auld, G.; Newsom, D. Governing through Markets: Forest Certification and the Emergence of Non-State Authority; Yale University Press: New Haven, CT, USA, 2004.

63. Rametsteiner, E.; Simula, M. Forest certification-An instrument to promote sustainable forest management? J. Environ. Manag. 2003, 67, 87-98. [CrossRef]

64. Auld, G.; Gulbrandsen, L.H.; McDermott, C.L. Certification schemes and the impacts on forests and forestry. Annu. Rev. Environ. Resour. 2008, 33, 187. [CrossRef]

65. Klooster, D. Environmental certification of forests: The evolution of environmental governance in a commodity network. J. Rural Stud. 2005, 21, 403-417. [CrossRef]

66. Gulbrandsen, L.H. Overlapping public and private governance: Can forest certification fill the gaps in the global forest regime? Glob. Environ. Politics 2004, 4, 75-99. [CrossRef]

67. Tian, T.; Poudyal, N.C.; Lu, F. Understanding landowners' interest and willingness to participate in forest certification program in China. Land Use Policy 2018, 72, 271-280. [CrossRef]

68. Liu, J.; Li, S.; Ouyang, Z.; Tam, C.; Chen, X. Ecological and socioeconomic effects of China's policies for ecosystem services. Proc. Natl. Acad. Sci. USA 2008, 105, 9477-9482. [CrossRef] [PubMed]

69. Chen, J.; Innes, J.L. The implications of new forest tenure reforms and forestry property markets for sustainable forest management and forest certification in China. J. Environ. Manag. 2013, 129, 206-215. [CrossRef] [PubMed]

70. Derissen, S.; Latacz-Lohmann, U. What are PES? A review of definitions and an extension. Ecosyst. Serv. 2013, 6, 12-15. [CrossRef]

71. Muradian, R.; Rival, L. Governing the Provision of Ecosystem Services; Springer Science \& Business Media: Berlin, Germany, 2012; Volume 4.

72. Abolina, E.; Luzadis, V.A. Forest sustainability and social policy: The role of ecosystem services. In Environmental Policy Is Social Policy-Social Policy Is Environmental Policy; Springer: Berlin, Germany, 2013; pp. 63-78.

73. Engel, S.; Pagiola, S.; Wunder, S. Designing payments for environmental services in theory and practice: An overview of the issues. Ecol. Econ. 2008, 65, 663-674. [CrossRef]

74. Van Hecken, G.; Bastiaensen, J. Payments for ecosystem services: Justified or not? A political view. Environ. Sci. Policy 2010, 13, 785-792. [CrossRef]

75. Fisher, B.; Turner, K.; Zylstra, M.; Brouwer, R.; de Groot, R.; Farber, S.; Ferraro, P.; Green, R.; Hadley, D.; Harlow, J. Ecosystem services and economic theory: Integration for policy-relevant research. Ecol. Appl. 2008, 18, 2050-2067. [CrossRef] [PubMed]

76. Greiner, R.; Stanley, O. More than money for conservation: Exploring social co-benefits from PES schemes. Land Use Policy 2013, 31, 4-10. [CrossRef]

77. Grieg-Gran, M.; Porras, I.; Wunder, S. How can market mechanisms for forest environmental services help the poor? Preliminary lessons from Latin America. World Dev. 2005, 33, 1511-1527. [CrossRef]

78. Pagiola, S. Payments for environmental services in Costa Rica. Ecol. Econ. 2008, 65, 712-724. [CrossRef]

79. Arriagada, R.A.; Ferraro, P.J.; Sills, E.O.; Pattanayak, S.K.; Cordero-Sancho, S. Do payments for environmental services affect forest cover? A farm-level evaluation from Costa Rica. Land Econ. 2012, 88, 382-399. [CrossRef]

80. Hein, L.; van der Meer, P.J. REDD+ in the context of ecosystem management. Curr. Opin. Environ. Sustain. 2012, 4, 604-611. [CrossRef]

81. McNally, R.; Sage, N.; Holland, T. Understanding REDD: Implications for Lao PDR, Nepal and Vietnam; SNV: Kathmandu, Nepal, 2009.

82. Poudel, M.; Thwaites, R.; Race, D.; Dahal, G.R. REDD+ and community forestry: Implications for local communities and forest management-a case study from Nepal. Int. For. Rev. 2014, 16, 39-54. [CrossRef] 
83. Corbera, E.; Kosoy, N.; Tuna, M.M. Equity implications of marketing ecosystem services in protected areas and rural communities: Case studies from Meso-America. Glob. Environ. Chang. 2007, 17, 365-380. [CrossRef]

84. Schröter, M.; Zanden, E.H.; Oudenhoven, A.P.; Remme, R.P.; Serna-Chavez, H.M.; Groot, R.S.; Opdam, P. Ecosystem services as a contested concept: A synthesis of critique and counter-arguments. Conserv. Lett. 2014, 7, 514-523. [CrossRef]

85. Redford, K.H.; Adams, W.M. Payment for ecosystem services and the challenge of saving nature. Conserv. Biol. 2009, 23, 785-787. [PubMed] article distributed under the terms and conditions of the Creative Commons Attribution (CC BY) license (http:/ / creativecommons.org/licenses/by/4.0/). 